\title{
AN ETHICS MODEL TO DEVELOP AN ETHICAL ORGANISATION
}

\section{Authors:}

Hendrik R. Lloyd

Michelle R. Mey ${ }^{1}$

\section{Affiliations:}

${ }^{1}$ Faculty of Business and

Economic Sciences, Nelson

Mandela Metropolitan

University, Port Elizabeth,

South Africa

\section{Correspondence to:}

Hendrik Lloyd

email:

Hendrik.Lloyd@nmmu.ac.za

\section{Postal address:}

PO Box 77000, Nelson

Mandela Metropolitan

University, Second Avenue

Campus, Port Elizabeth

6031, South Africa

\section{Keywords:}

automotive industry; ethics; ethical behaviour; human resources; ethical organisation

\section{Dates:}

Received: 12 May 2009

Accepted: 05 Aug. 2010

Published: 18 Nov. 2010

How to cite this article:

Lloyd, H.R., \& Mey,

M.R. (2010). An ethics

model to develop an

ethical organisation. $S A$

Journal of Human Resource

Management/SA Tydskrif vir

Menslikehulpbronbestuur, $8(1)$

Art. \#218, 12 pages. DOI:

10.4102/sajhrm.v8i1.218

\section{This article is available} at:

http://www.sajhrm.co.za
(C) 2010. The Authors.

Licensee: OpenJournals

Publishing. This work

is licensed under the

Creative Commons

Attribution License.

\begin{abstract}
Orientation: As background to the study it can be stated that the ethical conduct of employees in an organisation is of paramount importance to the successful operations of an organisation, both real and perceived. In recent times the ethical conduct of employees has received extensive publicity and, as such, has emphasised the impact of organisational ethics on the global competitiveness of organisations.
\end{abstract}

Research purpose: The main aim of the paper is to analyse the impact of business ethics in the Eastern Cape Motor Industry Cluster (ECMIC) and the different perceptions regarding such ethics. This is based on the main research question, namely, whether a business ethics model should be developed to assist in creating an ethical organisation.

Motivation of the study: The motivation for this study is based on the question of whether there is a dedicated drive within the motor industry to establish an ethical organisation and, if such is the case, what benefits would accrue to the organisations in ECMIC.

Research design, approach and method: An empirical study was conducted within ECMIC to test the proposed ethics intervention model. A questionnaire, as the main measuring instrument, was developed and 150 questionnaires were distributed. Statistical hypothesis testing was used, with a significance level set at $5 \%$. The aim of the hypothesis testing was to test whether the percentage responses in certain categories were significantly higher than a pre-determined testvalue.

Main findings: The research results substantiate the fact that the majority of the surveyed organisations do not implement specific ethics interventions. Nevertheless, the majority of respondents acknowledge the importance of ethical behaviour in the organisation, especially with regard to their financial positions.

Practical/managerial implications: From this study it became clear that the implementation of a code of ethics would create a platform for ethical behaviour in organisations. It is also concluded from this study that all organisations must strive towards creating an ethical organisation which would have long-term rewards for the organisation, especially from a financial perspective.

Contribution/value-add: This study highlights the fact that although ethics and ethical behaviour in organisations are emphasised and receive wide-spread media coverage, not enough action is linked to this task at hand. The results of this research clearly indicate where the shortcomings are, in the process of establishing ethical organisations and who should be seen as the custodians of such activities.

\section{INTRODUCTION}

\section{Key focus of the study}

This article proposes a model for the establishment and support of ethical organisations. The model will ensure that ethical change in the organisation is managed effectively by ensuring that all the necessary interventions in order to improve on the ethical environment are implemented. The proposed model provides logical, practical and uncomplicated guidelines to organisations that intend to improve or establish an ethical organisation.

The proposed model distinguishes between critical interventions and optional interventions. Four critical interventions are identified that are required to institutionalise ethical behaviour within an organisation. All four interventions are essential if the behaviour of the employees is to be aligned to that of an ethical organisation.

\section{Background to the Study}

Since the 1990s there have been daily reports of mismanagement and unethical actions by members of organisations. Furthermore, the ethical conduct of employees in organisations has received extensive attention and publicity. Mathis and Jackson (2000, p. 30) provide feedback on a survey that resulted in $48 \%$ of respondents stating that they were unethical at work. Examples of unethical behaviour are 'cheating on expense accounts, paying or accepting bribes and kickbacks, forging signatures and lying about sick leave'. Esterhuyse (1999, p. 27) reports that South Africa has lost significantly large amounts of money due to office or white-collar crime.

Organisations' attempts to become globally competitive will be hampered by employees who are unethical at work. Ethics in the economic life of transitional economies is a delusion rather than the reality'; therefore ethical behaviour is becoming more important as communities begin to realise its significance (Fülöp, Hirsrich \& Szegedi, 2000, p. 1). Fülöp et al. (2001, p. 1) believe that research on business ethics needs to begin with an understanding of the nature of business ethics. For the purpose of this study an ethical organisational environment can be described as the behaviour, 
norms, rules and values that are inherently honest and just and are shared by all employees within an organisation with the aim of continuously improving performance, achieving common goals and establishing relationships with all stakeholders.

Kay and Popkin (1998, p. 337) believe that organisations that wish to improve their profitability need to enhance their decision-making strategies by incorporating ethics into their decisions. Similarly in a comparable study conducted by the Du Paul University during 1999, it was found that organisations that make an explicit commitment to follow an ethical code provided more than twice the value to shareholders' than organisations that did not. It was also found that 47 organisations that had a more extensive commitment to ethics indicated that their market value added (MVA) was larger by an average of $\$ 10.6$ billion, or approximately three times the MVA of organisations without similar commitments (Salopek 2001, p. 1). According to Charlesworth and Sewry $(2003$, p. 113$)$ it was found during a South African survey in the IT sector that $65 \%$ of respondents believed that by being ethical an organisation can earn a profit in the long term. Rossouw (2008, p. 77) suggests that preventing corporate moral failure requires a total transformation of the organisation's ethical environment.

The above section highlights the need for creating an ethical organisation.

\section{Trends from research literature}

The importance of an ethical organisation has been emphasised. The role played by all the stakeholders in the organisation in establishing an ethical organisation is critical to its success. Ethics in the workplace can be managed through implementing an ethics code of conduct, obtaining top management commitment and support, the appointment of an ethics officer ethics training, reward systems, a system to report unethical behaviour and the auditing of ethical performance (Emiliani, 2000, p. 2; Goosen \& Van Vuuren, 2005, p. 61; McNamara, 1999, p. 4; Rossouw, 2002, p. 405; Spangenberg \& Theron, 2005, p. 1; Van Vuuren, 2002, p. 22). However, this change cannot be achieved without using a practical model to attain organisational ethical goals. To develop a model that will assist in establishing an ethical organisation it is necessary to explore and discuss the inherent characteristics of such an organisation.

Trevino and Nelson (1995, p. 202) and Schein (1995), as quoted by Gottlieb and Sanzgiri (1996, p. 1277), believe that leadership is critical in creating, establishing and maintaining an ethical organisation. Therefore ethical behaviour to establish an ethical environment will begin with the leaders within the organisation as integrity, or the lack of it, flows from the top down (Emiliani, 2000, p. 261).

According to the Deloitte \& Touche survey (Deloitte LLP Ethics \& Workplace Survey, 2007, p. 1) leaders in the organisation play a pivotal role in setting the climate, whether ethical or unethical, in that organisation. From research conducted by Kelly (1989) and reported by Gottlieb and Sanzgiri (1996, p. 1278), 75\% of 8000 respondents agreed that the organisation's leader 'plays the most significant role in establishing ethical standards for the organisation'. Gottlieb and Sanzgiri (1996, p. 1278) suggest that the leader should contribute to and drive the formulation of the ethical policy, communicate the ethical code of conduct and lead by example with regard to ethical management.

Organisations attempting to implement ethics must adopt some form of ethical learning and training (Costa, 1998, p. 93). McDonald and Pak (1996, p. 974) are convinced that the promotion of business ethics cannot be successful without the implementation of ethics training.

The simple provision of ethics training to employees is not sufficient to change the organisational environment, but rather thought must be given to the type of training, the timing and the methodology that are required. Therefore, Trevino and Nelson (1995, p. 208) as well as White, Sharar and Funk (2001, p. 40) take the standpoint that baseline training and continuing ethics education and training programmes should be provided for all individuals within the organisations. Ethics training should commence with formal orientation training for all new employees and should be reinforced by continuous training interventions. Participants in the training would also include part-time workers, contractors and contingency workers. This would ensure that all employees, regardless of their type of employment contract, are aware of the ethical standards and behaviour that is expected of them in an ethical organisation.

An ethical survey conducted by KPMG, Public Service Commission and Transparency South Africa, Malan and Smit (2001, p. 4) and Nicolaides (2009, p. 490), found that the ethics training that organisations provide is too brief and does not include new employees and managers. Only 27\% of the respondents indicated that new employees were being trained to apply the organisation's code of ethics while $13 \%$ of new employees were being trained in ethical decision-making skills. It can thus be construed that South African organisations are not yet prepared to invest in changing the behaviour and competencies of their employees to conform to those of an ethical organisation.

According to Trevino and Nelson (1995, p. 205), organisations attempt to guide employees' behaviour through formal organisational value statements, mission statements, credos, policies and formal codes of ethical conduct. Organisations are becoming more cognizant of the consequences of violating legal or ethical standards and are therefore implementing codes of conduct or ethics that prescribe standards of behaviour for all employees (Darley, Messick \& Tyler, 2001, p. 40). Therefore a written code of conduct formally acknowledges the organisation's intent to undertake business in an ethical manner (Kreuze, Luqmani \& Luqmani, 2001, p. 48; Ebert \& Griffen, 2000, p. 82). A well-developed code of ethics can assist the organisation in fostering an ethical environment, discouraging unethical behaviour and coping with ethical problems and dilemmas. The code of ethics establishes the ground rules by which the organisation operates. In a recent study of Fortune 500 companies in the United States of America, $90 \%$ of respondents indicated that a code of ethics existed (Erasmus, 2002, p. 34). The Du Paul University study mentioned previously reinforces the theory that an ethics code and ethical organisational environment contribute to the financial viability of an organisation. The KPMG survey of 2003 reported that $77 \%$ of the respondents indicated that their organisation had adopted a code of ethics or corporate code of conduct.

However, the mere existence of an ethics code of conduct does not guarantee ethical behaviour. It is imperative that the process of developing and communicating the code to all stakeholders be done in a transparent and consultative manner (Rossouw and Van Vuuren, 2010, p. 241). It is also important to ensure that the code is enforced throughout the organisation. Failure to enforce the code will ultimately result in it losing its legitimacy and being perceived as window dressing (Trevino \& Nelson, 1995, p. 207).

The ethics officer plays a pivotal role in driving the ethical environment within the organisation. According to DiPiazza (2001, p. 717), the ethics officer needs to identify the ethical issues and mobilise resources and persons around these issues. Allowing people to talk about ethical issues via meetings (or even in 'chat rooms') on the organisation's intranet, can achieve this. DiPiazza (2001, p. 717) believes that the position of an ethics officer should be independent of management and of the business operations. However, the incumbent should possess an understanding of the business environment. DiPiazza (2001, p. 718) believes that the ethics officer should not be seen as a member of the management team, but as an individual who is positioned across the organisation and who reports to the board of Directors. 
The most effective indication that an organisation is committed to ethical conduct in all of its business operations is the appointment of an ethics officer. This appointment formalises the organisation's commitment to ethical practices and conduct. However, it is critical that the ethics officer has a clear and measurable mandate within which to operate. Linked to the appointment of an ethics officer would be the installation of a centralised hotline where employees can obtain advice on ethical matters and lodge ethical complaints. When requesting advice or informing on an unethical action, the individual can remain anonymous. This anonymity is considered to be the immense advantage of a hotline. The hotline is considered a tool that assists in enforcing the ethical standards within the organisation and providing employees with answers to policy questions (Koehn, 1998, p. 125)

According to Dessler (1997, p. 109), a growing number of modern organisations have fewer supervisory and management levels, with the result that fewer employees are being supervised. Organisations rely on employees to report misconduct; the act of reporting misconduct is known as whistle-blowing.

Campbell, as quoted by Richter, Burke and Doig (1990, p. 197), offers a definition of whistle-blowing: 'the disclosure of legal violations, mismanagement, a gross waste of funds, an abuse of authority or a danger to the public health or safety of individuals'. The said disclosure can be made within or outside of the chain of command. Whistle-blowing is therefore the act of informing on organisations and individuals that commit illegal or unethical acts, provide poor value for money, or endanger the health and safety of employees or stakeholders. Organisations can reduce these conflicts by affording protection to whistle-blowers in the organisation's code of ethics, perhaps by installing a hotline or appointing an ombudsman to ensure confidentiality and reduce the fear of retaliation. Conversely, should the whistle-blower's allegations be false and the individual intentionally attempts to discredit an individual or the organisation, the whistle-blower must be penalised or dismissed. This should prevent frivolous action on the part of potential whistle-blowers.

An organisation's reward system is a critical component of the ethical organisation and it contributes to the alignment or misalignment of systems (Trevino \& Nelson, 1995, p. 207). An ethics-focused reward system is a formal reward system that will promote, measure and reward the ethical behaviour of employees (Lindsay, Lindsay \& Irvine, 1996, p. 394). Trevino and Nelson (1995, p. 207) believe that in order to comprehend the ethical conduct of individuals in the organisation, it is important to investigate the behaviours that are rewarded and punished. It is also important that management ensures that the concern with the financial bottom line does not conflict with the ethical goals of the organisation.

Reward systems in organisations are important as they provide guidance about what behaviour is expected and also reflect what is valued in the organisation. Therefore it is critical that organisations reward the 'correct' behaviour, otherwise misalignment of the reward system with other aspects of ethics will occur. Individuals are encouraged to behave ethically or unethically when they are incentivised to do so; therefore it is important that managers examine the current reward system to ensure that the preferred behaviour is reinforced (Kreitner \& Kinicki, 2001, p. 93; Navran, 1997, p. 122).

An ethical organisation can only be created and sustained by establishing a reward system for those employees who contribute to the organisation's ethical objectives.

Organisations of different sizes and types have indicated and proved their commitment to ethical practices by:

- implementing policies that integrate ethics into the organisation's values and mission, develop ethics codes

- implement ethics training
- $\quad$ establish an ethics hotline, audit ethical performance and link it with rewards and sanctions

- create ethics committees and revise internal structures to achieve their ethical objectives (Navran, 1997, p. 1).

In order for the ethical environment to be significantly impacted on it is imperative that all stakeholders 'buy in' to the vision of the organisation becoming more ethical.

\section{What will follow}

The following section proposes a model for the development of an ethical organisation. The model can guide ethical change in the organisation by ensuring that all the interventions that are needed in order to improve on the ethical environment are implemented. The proposed model provides logical, practical and uncomplicated guidelines to organisations that intend to improve or establish an ethical organisation.

\section{DEVELOPING AN ETHICS INTERVENTIONS MODEL}

The proposed model distinguishes between critical interventions and optional interventions. Four interventions are identified as being critical to institutionalising ethical behaviour. All four interventions are essential if the behaviour of the employees is to be aligned to that of an ethical organisation. The choice to implement the optional interventions would depend on the organisation's size and resources available. The smaller the organisation and the fewer the resources, the higher the probability that the optional interventions will not be implemented. The critical interventions ethical model is presented in Figure 1 and a comprehensive discussion will follow.

Robbins and Judge (2007, p. 441) are of the opinion that top management establishes the 'moral tone' for the organisation by setting and demonstrating high ethical standards and encouraging and rewarding integrity in others.

\section{Top management commitment}

Stage 1: In the creation of an ethical organisation, the leadership is an essential component, seeing as leaders can create, maintain or change environment (Trevino \& Nelson, 1995 , p. 200). Support for the ethics initiative must be elicited from senior management. They can indicate their commitment by participating in training sessions and including ethics as a regular element in speeches and presentations, as well as ensuring that their behaviour is an example to all employees.

\section{Code of ethics}

Stage 2: A code of ethics provides guidelines for ethical decision-making. Hosmer (1987) as quoted by Kitson and Campbell (1996, p. 123) defines an ethical code as 'statements of the norms and beliefs of an organisation with the intention to encourage ways of thinking and patterns of attitude that will lead towards the wanted behaviour'. The code of ethics allows the organisation to define its position on being an ethical organisation, in order that all employees and stakeholders are clear as to what the organisation values (Rossouw, 2002, p. 216). Kitson and Campbell (1996, p. 108) believe that the code of ethics provides advice and guidelines concerning expected employee behaviour. Cassell, Johnson and Smith (1997, p. 1078) state that a code of ethics is an important method of institutionalising ethics in an organisation. The compiling of the code of ethics can be coordinated by the human resource manager or practitioner. It is imperative that a task team comprising of individuals representing a variety of functions and from different levels of the organisation be created in order to assist with the writing and implementing of the code.

According to Malan and Smit (2001, p. 175), when a code of ethics is properly designed and 'managed with integrity as a living, dynamic, cultural guide and discipline there should be no doubt about the moral foundation of the organisation'. 


\section{Ethics training}

Stage 3: Rossouw (2002, p. 240) believes that ethics training should be provided to employees in order to expose them to the concept of ethics and to empower them with skills to make ethical decisions. A comprehensive programme of ethics training needs to be designed and implemented in order to create and maintain an ethical organisation. Training can include lectures, videos, 'cascade' training which is presented by direct supervisors, web- or computer training, games, quizzes, case studies, role plays and simulations. Consideration must be given to designing specialised training for those individuals who may be confronted by special ethical
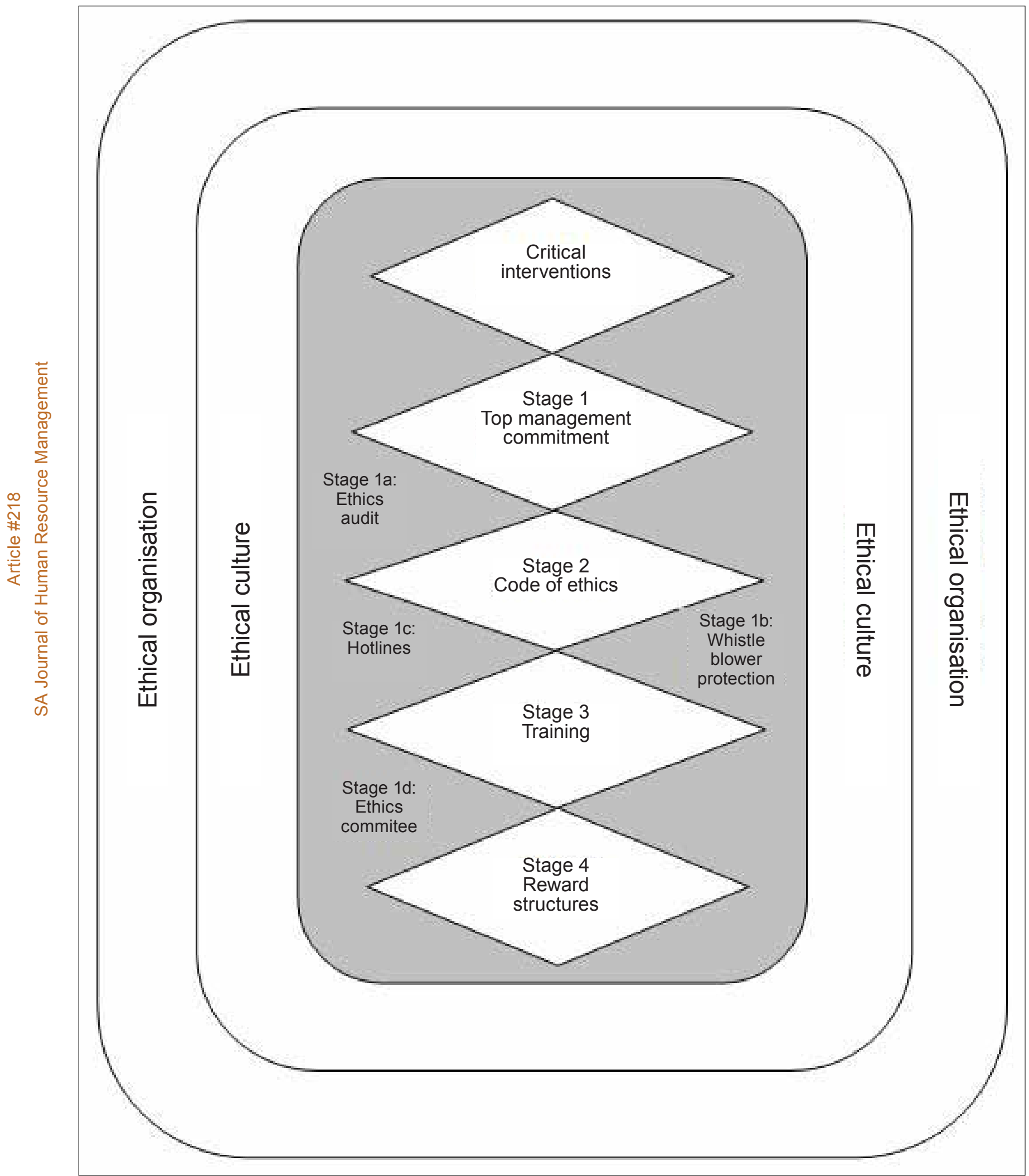

FIGURE 1

Proposed Ethics Interventions Model 
dilemmas, for example, working in countries where bribery is commonplace. The training department will take responsibility for the coordinating and organising of the ethics training, as they are the specialists in this field.

\section{Reward structures}

Stage 4: In order to ensure that ethical expectations are understood and followed by organisational members, ethical values and guidelines must be reinforced. Reward systems for employees who contribute to the organisation's ethics goals and objectives must be established. Trevino and Nelson (1999, p. 151) and Rossouw (2002, p. 239) state that reward systems are the 'single most important formal influence' on employees' behaviour at work. Incentives must be integrated into the performance and compensation system. A percentage of bonuses can be linked to ethical performance. Formal performance appraisals are used to determine and allocate these rewards and to reinforce behaviours consistent with expectations on a regular basis. The appraisals can also communicate and reinforce management's expectations as they relate to the performance of each employee (Logsdon \& Yuthas, 1997, p. 1222).

With the above interventions established as critical and compulsory interventions the following interventions are considered to be optional. The use of these optional interventions will be dependent on the organisation's size and the resources available to implement each option.

\section{Ethics audit}

Stage 1a: Kitson and Campbell (1996, p. 108) recommend that an ethics audit be conducted prior to implementing an ethics initiative as one can analyse the organisation's environment in order to determine the current behaviour and operations within the organisation. An alternative explanation of an ethics audit is provided by Carroll and Buchholtz (2003, p. 235), who believe that the ethics audit serves the purpose of assessing or evaluating the ethical status and ethical programmes offered by the organisation. An ethics audit will also highlight certain problem areas that may require special attention from the ethics coordinator. Ethics audits are intended to review 'ethics initiatives such as codes of conduct, hotlines and ethics training programmes' (Carroll \& Buchholtz, 2003, p. 235). After training, regular evaluations can be conducted to ensure that employees are retaining what they have learnt and transferring it to the workplace. Regular audits of the ethics programme should be completed in order to determine the success of the ethics initiative. Regular audits will also highlight the benefits of the ethics programme to management, thereby ensuring continued resources.

\section{Whistle-blower protection}

Stage 1: A whistle-blower will expose illegal, immoral or illegitimate practices that occur within the organisation. Lindsay, Lindsay and Irvine (1996, p. 401) are of the opinion that organisations function in a complex and risky environment with legislation and regulatory standards rapidly changing, therefore it becomes difficult to determine what constitutes ethical behaviour. As a result it is important to implement processes that will encourage open discussion and resolve conflict. A whistle-blower system can achieve this. According to Carroll and Buchholtz (2003, p. 495), whistle-blowers are not rewarded for their perceived contributions to public interest.

In order to avoid some of the different forms of retaliation, such as more severe criticism of work, less attractive work assignments, heavier workloads, lost privileges and exclusions from meetings previously attended, it is important that organisations implement some form of whistle-blower protection. Protection would be included in the code of ethics. Winstanley and Woodall $(2000$, p. 7) state that, traditionally, human resource managers administer disciplinary and grievance procedures and they therefore propose that the human resource manager create and administer whistle-blowing procedures as well.

\section{Hotlines}

Stage 1c: A highly effective ethical environment is contingent on employees having a mechanism for reporting unethical acts (Carroll \& Buchholtz, 2003, p. 233). As reported by various authors the most common whistle-blowing mechanism is a hotline (Carroll \& Buchholtz, 2003, p. 233; Malan \& Smit, 2001, p. 157; Rossouw, 2002, p. 143; Trevino \& Nelson, 1999, p. 71; Wixley \& Everingham, 2002, p. 83). Medium and large organisations can establish a hotline, so that employees can raise ethical concerns that they do not feel comfortable discussing with their supervisors.

\section{Ethics committee}

Stage 1d: The ethics committee can manage the ethics function in a large organisation. In smaller organisations an appointed ethics officer or the human resource practitioner can perform the role of the ethics committee. According to van Vuuren and Eiselen (2006, p. 22), few South African organisations have appointed ethics officers. When compiling the ethics committee, it is recommended that persons from diverse functions and representative of the organisation in terms of gender and race be included. It is advisable that a trade union representative be included on the committee. The ethics committee should be an advocate for effective ethics management and play an executive and leadership role. The committee will represent the organisation's and employees' interests by ensuring that the ethics initiatives of the organisation are effective and meet the requirements of applicable law and guidelines (Carroll \& Buchholtz, 2003, p. 226)

Kile (1992, p. 1) outlines the possible roles of an ethics committee. Ethics committees are responsible for:

- contributing to the continuing definition of the organisation's standards and procedures

- assuming responsibility for overall compliance with those standards and procedures

- overseeing the use of due care in delegating discretionary responsibility

- communicating the organisation's standards and procedures, ensuring the effectiveness of that communication

- monitoring and auditing compliance

- overseeing enforcement, including the assurance that discipline is uniformly applied.

The ethics committee will implement steps and strategies to ensure that the organisation learns from its experiences. In summary, the ethics committee should examine issues, make decisions, formulate strategies and direct programme implementation through the programme director.

\section{RESEARCH DESIGN}

The main research question for this study can be formulated as follows: Can a business ethics model be developed to assist in creating an ethical organisation?

\section{Hypotheses}

Based on the above research question and using ECMIC as the study platforms the following hypotheses were tested.

Hypothesis 1: ECMIC is an ethical organisational structure.

Hypothesis 2: Individuals within ECMIC subscribe to the principles of an ethical organisation.

Hypothesis 3: There is a dedicated drive and initiative within ECMIC to establish an ethical organisation.

Hypothesis 4: It is beneficial to establish an ethical organisation within ECMIC. 


\section{Hypotheses testing procedure}

Statistical hypothesis testing was used where the significance level was set at $5 \%$. The aim was to test whether the percentage responses in certain categories were significantly higher than a value of $65 \%$ pre-determined by the researchers.

The hypotheses were:

$\mathrm{H}_{\mathrm{o}}: p=0.65$

$\mathrm{H}_{1}: p>0.65$

where $p$ indicates the population proportion.

For each hypothesis where the sample proportion was greater than $65 \%$, a test statistic was calculated and compared with the one-sided standard normal value at 5\%, namely 1.645 .

Values of the test that exceeded 1.645 indicated that the corresponding sample proportion was significantly greater than $65 \%$. No tests were performed in cases where the sample proportions were less than $65 \%$.

\section{Research method}

\section{Sampling and data collection methods}

An empirical study was conducted within the automotive cluster of the Eastern Cape Province to test the proposed ethics interventions model. A clustered, random convenience sampling method was used. A mailing list of the participants was compiled. Each participant was allocated a number and as each completed questionnaire was received, the participant was checked off the list. A research assistant contacted nonrespondents telephonically and via email to encourage them to return the completed questionnaire as speedily as possible.

Data collection was facilitated by means of a questionnaire. The questionnaire was designed and developed with the assistance of a research statistician at the university. The questionnaire consisted of two sections. Section A was used to obtain biographical information on the respondent organisation, while section $\mathrm{B}$ provided data regarding the interventions and ethical strategies used by the respondent organisation. To ensure that the questionnaire would measure the concept or attribute it was supposed to measure, it was subjected to a pilot study. Feedback from this pilot study was used to improve the questionnaire and consequently both face validity and construct validity was established.

One hundred and fifty questionnaires were distributed amongst 75 organisations within ECMIC. On average, two questionnaires were sent to each organisation, one to the CEO's office and one to the human resource manager or department. A total of 88 completed questionnaires were received which indicates a $58.6 \%$ response rate.
Section A of the questionnaire required respondents to provide general biographical information. These questions were included to highlight independent variables, in order to facilitate comparisons between the dependent variables obtained from responses to questions in other sections of the questionnaire.

Organisations of all sizes within the automotive cluster were represented in the responses obtained. The highest percentage of responses $(43.7 \%)$ was from organisations exceeding 300 employees, followed by organisations with between 101 and 200 employees (18. 4\% rate).

The majority of organisations $(54.8 \%)$ that responded are classified as functioning in manufacturing automotive components, followed by automobile manufacturers (19\%) and other related industries such as the paint industry $(16.7 \%)$, metal industries (7.1\%) and tyre and rubber manufacturers $(2.4 \%)$.

\section{Recording of data and analysis methods}

The responses to the items in questions dealing with ethics interventions and the characteristics of an ethical organisation are measured on 5-point ordinal scales. The different levels of the scales have been assigned the numerical values 1-5 and assuming equal distances between adjacent levels, the level of measurement is now an interval scale which allows for parametric statistical analysis based on means, standard deviations and correlations.

There were a number of non-responses on these questions; a maximum of 7 on one item was detected. In order not to lose any cases due to missing data, the missing values on each item were replaced by the mean value of the valid data for that item.

Each of the four questions has a number of items, related to a specific topic. Each set of related items was analysed to see whether they correlate to such an extent that a total score can be calculated that reflects the respondents' feeling towards the topic as a whole. To accomplish this, principal component analysis was performed on each set of items. Such an analysis shows, inter alia, the maximum percentage of the total variation in the set of items that can be explained by only one (linear) composite score.

In order to measure the internal consistency of each set of items, that is, the extent to which they measure the same construct, Cronbach's alpha coefficient was calculated. This coefficient ranges from zero to one where small values are an indication of low internal consistency and big values (close to one) are an indication of high internal consistency.

\section{Reporting}

The results of the above mentioned analyses are summarised in Table 1.

TABLE 1

Principal component analysis: ethics interventions and characteristics of ethical organisations

\begin{tabular}{|c|c|c|c|c|c|c|}
\hline \multirow[t]{2}{*}{ Question } & \multirow[t]{2}{*}{ Number of items } & \multirow[t]{2}{*}{$\%$} & \multicolumn{3}{|c|}{ Correlation } & \multirow[t]{2}{*}{ Alpha coefficien } \\
\hline & & & Average & Minimum & Maximum & \\
\hline B6 (extent of ethical intervention) & 8 & $48.30 \%$ & 0.41 & 0.10 & 0.64 & 0.84 \\
\hline B7 (establishment of an ethical organisation) & 8 & $56.80 \%$ & 0.51 & 0.29 & 0.70 & 0.88 \\
\hline B9 (ethical environment) & 5 & $53.50 \%$ & 0.42 & 0.29 & 0.56 & 0.77 \\
\hline B10 (characteristics of an ethical organisation) & 6 & $49.10 \%$ & 0.38 & 0.01 & 0.66 & 0.77 \\
\hline
\end{tabular}

$\%$ Maximum variation explained by on

TABLE 2

Principal component analysis: ethics interventions and characteristics of ethical organisations (low correlation variable removed)

\begin{tabular}{|c|c|c|c|c|c|c|}
\hline \multirow[t]{2}{*}{ Question } & \multirow[t]{2}{*}{ Number of items } & \multirow[t]{2}{*}{$\%$} & \multicolumn{3}{|c|}{ Correlation } & \multirow[t]{2}{*}{ Alpha coefficien } \\
\hline & & & Average & Minimum & Maximum & \\
\hline B6 (extent of ethical intervention) & 7 & $52.40 \%$ & 0.45 & 0.33 & 0.64 & 0.85 \\
\hline B10 (characteristics of an ethical organisation) & 5 & $57.20 \%$ & 0.47 & 0.28 & 0.66 & 0.79 \\
\hline
\end{tabular}

Maximum variation explained by one score. 
Although the alpha values are all at an acceptable level $(>0.70)$, the two low correlations in the 'Minimum correlation' column led to the inspection of the items of B6 and B10. The fourth item of B6 was the one that had a few low correlations and was also the minimum of 0.10 . An item analysis also showed that this item had a much lower item-total correlation (0.38) than the other items (0.54 or higher). Amongst the items of B10, it was the first item that had a number of low correlations, including the minimum of 0.01 . The item-total correlation of this first item was also much lower $(0.23)$ than that of the other items $(0.48$ or higher).

Table 2 gives the information for B6 and B10 when the two items that do not seem to strongly belong to the construct had been removed.

It is clear from the above table that by removing the two items, the remaining items are much more coherent and will lead to the measuring of more consistent constructs.

A principal component analysis on each of the four sets of items revealed that, in each case, the linear combination of items that contained the maximum information (variation) was a weighted sum of the items. Seeing that the weights differed only slightly, it was decided to use as composite score the arithmetic mean of the items, which is easy to interpret and on a scale of $1-5$.

In testing the hypotheses and according to the pre-determined $65 \%$ value, the following results were obtained as expounded in tabular format.

Table 3 indicates that $91.1 \%$ of the survey sample indicated their organisation to be 'highly ethical', or at least 'ethical'. The resulting test statistics were calculated at 5.79 indicating the corresponding sample proportion to be significantly greater than $65 \%$, therefore subscribing to the alternative hypothesis. From the responses it was further noted that:

\section{TABLE 3}

Organisational environment

\begin{tabular}{lccc}
\hline Question & Categories & Sample proportion & Test statistic \\
\hline $\begin{array}{l}\text { B1 (rating of organisational } \\
\text { environment) }\end{array}$ & $\begin{array}{c}\text { Highly ethical } \\
\text { or ethical }\end{array}$ & $91.10 \%$ & 5.79 \\
\hline Source: Question B1 & &
\end{tabular}

TABLE 4

Services offered by the organisation that underpin ethics in the organisation

\begin{tabular}{|c|c|c|c|}
\hline Question & Categories & Sample proportion & Test statistic \\
\hline $\begin{array}{l}\text { B3.1 (code of ethics / } \\
\text { conduct) }\end{array}$ & Yes & $75.90 \%$ & 2.42 \\
\hline B3.2 (ethics training) & Yes & $29.40 \%$ & - \\
\hline $\begin{array}{l}\text { B3.3 (employment of } \\
\text { ethics officer) }\end{array}$ & Yes & $38.50 \%$ & - \\
\hline $\begin{array}{l}\text { B3.4 (whistle-blower } \\
\text { protection) }\end{array}$ & Yes & $67.90 \%$ & 0.63 \\
\hline B3.5 (ethics audit) & Yes & $26.20 \%$ & - \\
\hline $\begin{array}{l}\text { B3.6 (reward ethical } \\
\text { behaviour) }\end{array}$ & Yes & $19.40 \%$ & - \\
\hline $\begin{array}{l}\text { B3.7 (hotline / helpline } \\
\text { to report misconduct) }\end{array}$ & Yes & $29.40 \%$ & - \\
\hline
\end{tabular}

to report misconduct)

Source: Question B3 (B3.1 - B3.7)

TABLE 5

Commitment to ethics in the organisation

\begin{tabular}{lccc}
\hline Question & Categories & Sample proportion & Test statistic \\
\hline B4.1 (CEO) & Yes & $74.80 \%$ & 2.13 \\
B4.2 (Senior Manager) & Yes & $70.90 \%$ & 1.30 \\
B4.3 (Direct Manager) & Yes & $81.30 \%$ & 3.53 \\
B4.4 (Colleagues) & Yes & $77.80 \%$ & 2.79 \\
B4.5 (Subordinates) & Yes & $74.50 \%$ & 2.01 \\
B4.6 (Employees) & Yes & $62.40 \%$ & - \\
\hline
\end{tabular}

- In $76 \%$ of organisations it was reported that a code of ethics existed that provided details on standards for ethical behaviour.

- Only $30 \%$ of organisations provided staff with training in business ethics. In a similar survey performed by Lindsay et al. (1996, p. 398) in Canada, it was reported that $29.8 \%$ of organisations had implemented or were in the process of implementing ethics training. This reflects a possible international trend that organisations are not investing resources into activities, such as ethics interventions, that directly affect the bottom line in the short term.

- It was reported that $39 \%$ of the respondents indicated that their organisations have an ethics officer to whom employees can report misconduct or obtain advice on ethical issues.

- The study revealed that $68 \%$ of respondents were aware of protection for individuals who report misconduct in their organisation.

- According to $74 \%$ of respondents, an ethics audit has not been conducted to determine the current ethical environment within their organisation.

- A large percentage of respondents (80\%) stated that rewarding ethical behaviour in the form of promotions or performance bonuses does not transpire. A similar survey conducted by Lindsay et al. (1996, p. 401) reported that $12 \%$ of sampled organisations used an ethics focused reward system. This is of concern because it indicates that organisations are not using positive reinforcement to encourage ethical behaviour and therefore significant achievement of the organisations' ethical goals may not be realised.

It is interesting to note that the majority of respondents reported that their organisation does not offer the above interventions. As these interventions are identified as being essential when creating an ethical organisational environment, one would assume that it would be difficult to characterise one's organisation as highly ethical or ethical if the above interventions were deficient.

In this analysis where the corresponding answer is 'yes', the sample percentage was calculated. Only in two cases, namely Questions B3.1 and B3.4, was a sample percentage of larger than $65 \%$ calculated (See Table 4 ).

From these two cases (Table 4) only Question B3.1 reflected a test statistic of larger than 1.645, namely 2.42, reflecting that from the proportion of organisations surveyed $(75.9 \%)$ the majority of respondents were in agreement that a code of ethics was in operation.

In Table 5, five of the six questions revealed a sample percentage larger than $65 \%$. Of that total, four questions had a test statistic larger than 1.645. These were questions B4.1, B4.3, B4.4 and B4.5. These results indicated a strong level of commitment from the Chief Executive Officer or the direct Manager, colleagues and subordinates.

The results with regard to the provision of ethics training are fairly consistent. The survey revealed that $30 \%$ of organisations have implemented ethics training or are in the process of implementing ethics training. This finding is consistent with the KPMG study that was conducted in 2001. In this study, Malan and Smit (2001, p. 4) found that South African organisations have not focused extensively on ethics training.

According to $23 \%$ of respondents, reward structures that encourage ethical behaviour had been implemented or are in the process of being implemented. The study further shows that $20 \%$ of organisations had implemented a hotline for persons to report misconduct.

The study also indicates that $21 \%$ of organisations had implemented or are planning on implementing an ethics committee, which constitutes a formally specified group of 
employees responsible for developing, updating and enforcing the code of ethics (Lindsay et al., 1996, p. 394). Finally, 37\% of respondents stated that their leaders display ethical leadership.

Very small percentages of respondents indicated in this section of the questionnaire that their organisations were currently implementing the various ethical interventions. This is of concern as it may point toward a lack of seriousness being displayed by the automotive cluster in the Eastern Cape Province towards governing ethically. Malan and Smit (2001, p. 9) are convinced that developing an ethical organisation and all that is required to achieve this objective is for many South African organisations purely an optional experience and not a core business activity.

Table 6 indicates the perception of the respondents concerning the impact of identified interventions on the establishment of an ethical organisation. The results are based on the responses where the intervention is implemented or planned to be implemented. None of these responses reflected a sample percentage of larger than $65 \%$. This is indicative of the fact that the ethics intervention activities are not a major concern of surveyed organisations in ECMIC.

The respondents were also given the opportunity (refer to Table 7) to provide an indication of their opinion of the importance of the interventions, using a 5-point Likert scale that ranged from 'essential' to 'not essential'.

The results are based on the responses that ranged from essential to important. Three questions revealed a sample percentage of higher than $65 \%$, with all three having a test statistic of larger than 1.645. In this regard although the percentage of organisations that plan to implement the various ethical interventions is insignificant, individuals within the organisations indicated that the ethics interventions are important.

\section{FINDINGS AND DISCUSSIONS}

Table 8highlights certain characteristics of ethical organisations. Respondents were asked to report on their perceptions concerning whether the stated attributes characterised an ethical organisation. A 5-point Likert scale ranging from 'strongly agree' (1) to 'strongly disagree' (5) was used.

Three of the questions had a sample percentage of larger than $65 \%$ and all three revealed a test statistic of larger than 1.645 indicating their significance as characteristics of an ethical organisation. Ethics training, a code of ethics and whistleblower protection were highlighted as important characteristics of an ethical organisation.

In cross referencing Tables 1-8, certain deductions can be made. In the majority of cases, issues such as:

- a code of ethics

- ethics training

- whistleblower protection

stood central in the analysis, whilst achieving significant relevance in considering:

- the relative importance of ethical interventions

- the characteristics linked to an ethical organisation.

In a further analysis through the cross-tabulation of data, the frequency was determined and is being presented in Table 9 .

From this analysis it can be stated that the CEO is seen as the lead individual in implementing ethics in an organisation, followed by the HR department under the leadership of the HR manager.

From Table 9 it is clear that the HR department is responsible for organising ethics in the organisation, followed by the CEO. However, in terms of who should be responsible it is clear from Table 9 that the CEO is the preferred individual, followed by the HR manager. The chi-square analysis also indicates a statistically significant relationship between these variables $(p<0.05)$.

Table 10 reveals that the majority of respondents are not clear on the extent to which top management provides ethical leadership in the organisation. However, the majority of respondents do see the CEO as playing a leading role in exhibiting sufficient commitment to ethical business objectives. Based on the chi-

TABLE 6

Degree of ethical intervention adoption

\begin{tabular}{|c|c|c|c|}
\hline Question & Categories & Sample proportion & Test statistic \\
\hline B6.1 (code of ethics) & Implemented or implementation planned & $56.50 \%$ & - \\
\hline B6.3 (ethics training) & Implemented or implementation planned & $30.20 \%$ & - \\
\hline B6.4 (reward structures) & Implemented or implementation planned & $22.80 \%$ & - \\
\hline B6.6 (ethics Committee) & Implemented or implementation planned & $20.80 \%$ & - \\
\hline B6.7 (whistleblower protection) & Implemented or implementation planned & $36.80 \%$ & - \\
\hline
\end{tabular}

Source: Question B6 (B6.1, B6.3, B6.4, B6.6, B6.7)

TABLE 7

Relative importance of ethical intervention

\begin{tabular}{lccc}
\hline Question & Categories & Sample proportion & Test statistic \\
\hline B7.1 (Code of ethics) & Essential or important & $88.40 \%$ & 7.10 \\
B7.2 (Ethics training) & Essential or important & $75.70 \%$ & 2.36 \\
B7.3 (Reward systems) & Essential or important & $50.00 \%$ & - \\
B7.6 (Whistleblower protection) & Essential or important & $81.80 \%$ & 3.69 \\
B7.7 (Ethics Committee) & Essential or important & $60.20 \%$ & - \\
\hline
\end{tabular}

TABLE 8

Characteristics of an ethical organisation

\begin{tabular}{|c|c|c|c|}
\hline Question & Categories & Sample proportion & Test statistic \\
\hline B10.2 (ethics training) & Strongly agree or agree & $84.70 \%$ & 4.35 \\
\hline B10.3 (code of ethics) & Strongly agree or agree & $92.80 \%$ & 6.17 \\
\hline B10.5 (whistleblower protection) & Strongly agree or agree & $80.00 \%$ & 3.30 \\
\hline B10.6 (reward system) & Strongly agree or agree & $53.60 \%$ & - \\
\hline
\end{tabular}

Source: Question B10 (B10.2; B10.3; B10.5; B10.6) 
square analysis no statistically significant relationship could be determined between the variables $(p>0.05)$.

From Table 11 it is evident that the majority of respondents are not clear on the extent to which top management provides ethical leadership in the organisation. However, the majority of respondents were of the opinion that senior management does display a sufficient commitment to ethical business objectives. With a $p$-value of 0.00088 there is also a clear, statistically significant relationship between the variables $(p>0.05)$.

Most of the respondents, as is reflected in Table 12, are not clear on the extent to which top management provides ethical leadership in the organisation even though the King Report III (South African Institute of Chartered Accounts, 2009) places great emphasis on the role of ethical and effective leaders.

TABLE 9

Summary frequency table QB2(4) $\times$ QB5(4): who is responsible versus who should be responsible for ethics in the organisation

\begin{tabular}{lccccc}
\hline QB2 & HR Dept. & CEO & No-one & Other & All Groups \\
\cline { 2 - 6 } QB5 HR manager & 25 & 6 & 2 & 2 & 35 \\
QB5 CEO & 12 & 22 & 5 & 3 & 42 \\
QB5 Ethics officer & 2 & 2 & 6 & 3 & 13 \\
QB5 Other & 5 & 2 & 3 & 8 & 18 \\
Row totals & $\mathbf{4 4}$ & $\mathbf{3 2}$ & $\mathbf{1 6}$ & $\mathbf{1 6}$ & $\mathbf{1 0 8}$ \\
& & & & & \\
& & & Row \% & \\
QB5 HR manager & 56.82 & 18.75 & 12.50 & 12.50 & $\mathrm{n} / \mathrm{a}$ \\
QB5 CEO & 27.27 & 68.75 & 31.25 & 18.75 & $\mathrm{n} / \mathrm{a}$ \\
QB5 Ethics officer & 4.55 & 6.25 & 37.50 & 18.75 & $\mathrm{n} / \mathrm{a}$ \\
QB5 Other & 11.36 & 6.25 & 18.75 & 50.00 & $\mathrm{n} / \mathrm{a}$ \\
Row totals & $\mathbf{1 0 0}$ & $\mathbf{1 0 0}$ & $\mathbf{1 0 0}$ & $\mathbf{1 0 0}$ & n/a \\
\hline
\end{tabular}

Source: Questions B2 and B4

Pearson chi-square: $50.3114 ; \mathrm{df}=9 ; p=0.000000$
What is clear from the respondents is that the CEO is seen as the person who should be responsible, followed by the HR manager. There is a statistically significant relationship between the variables $(p>0.05)$.

As far as the $p$-values are concerned, all the values are smaller than 0.05 , indicating that there is a significant difference from the constant reference value. However, to make the table and the data more useful in terms of the objectives of the study, the 'effect size' column was introduced.

The effect size is a useful measure of the size of the difference (practical significance). In the case of a single sample $t$-test, the effect size is calculated as the difference between the mean and the reference value divided by the standard deviation. The effect size is called Cohen's $d$ and guidelines for its interpretation are:

- values in the region of 0.2 - small effect size

- values in the region of 0.5 - medium effect size

- values in the region of 0.8 - large effect size.

(Cohen, 1969)

The larger the effect size, the more practical the implementation is. From Table 13 it is clear that only three from the 18 variables have a small effect size, hereby implying that the majority of interventions identified in this study as per Table 13, will be practically implementable.

\section{CONCLUSION}

The concept of business ethics and corporate governance has dominated national and international news for the past decade and as a result organisations, their members and their operations are being scrutinised and criticised for unethical actions.

The purpose of this article was to propose a model that could be used when attempting to establish and maintain

TABLE 10

Summary frequency table QB6.8(5) × QB4.1(3): top management's ethical leadership and CEO commitment

\begin{tabular}{|c|c|c|c|c|c|c|}
\hline QB6.8 & Unknown & $\begin{array}{c}\text { Known but considered } \\
\text { unimportant }\end{array}$ & $\begin{array}{c}\text { Known and considered } \\
\text { unimportant }\end{array}$ & $\begin{array}{c}\text { Implementation is } \\
\text { planned }\end{array}$ & Implemented & All Groups \\
\hline & \multicolumn{6}{|c|}{ Count } \\
\hline QB4.1 Yes & 26 & 6 & 6 & 5 & 33 & 76 \\
\hline QB4.1 No & 7 & 2 & 2 & 2 & 1 & 14 \\
\hline QB4.1 Don't know & 8 & 0 & 1 & 0 & 3 & 12 \\
\hline \multirow[t]{2}{*}{ Row totals } & 41 & 8 & 9 & 7 & 37 & 102 \\
\hline & \multicolumn{6}{|c|}{ Row \% } \\
\hline QB4.1 Yes & 63.41 & 75.00 & 66.67 & 71.43 & 89.19 & $\mathrm{n} / \mathrm{a}$ \\
\hline QB4.1 No & 17.07 & 25.00 & 22.22 & 28.57 & 2.70 & $\mathrm{n} / \mathrm{a}$ \\
\hline QB4.1 Don't know & 19.51 & 0.00 & 11.11 & 0.00 & 8.11 & $\mathrm{n} / \mathrm{a}$ \\
\hline Row totals & 100 & 100 & 100 & 100 & 100 & $\mathrm{n} / \mathrm{a}$ \\
\hline
\end{tabular}

Source: Questions B6.8 and B4.1

Pearson chi-square: $12.0597 ; \mathrm{df}=8 ; p=0.148577$

TABLE 11

Summary frequency table QB6.8(5) $\times$ QB4.1(3): top management ethical leadership and senior management commitment

\begin{tabular}{|c|c|c|c|c|c|c|}
\hline QB6.8 & Unknown & $\begin{array}{c}\text { Known but considered } \\
\text { unimportant }\end{array}$ & $\begin{array}{c}\text { Known and considered } \\
\text { unimportant }\end{array}$ & $\begin{array}{l}\text { Implementation is } \\
\text { planned }\end{array}$ & Implemented & All Groups \\
\hline & \multicolumn{6}{|c|}{ Count } \\
\hline QB4.1 Yes & 21 & 6 & 5 & 5 & 37 & 74 \\
\hline QB4.1 No & 12 & 3 & 3 & 2 & 0 & 21 \\
\hline QB4.1 Don't know & 8 & 0 & 1 & 0 & 1 & 10 \\
\hline \multirow[t]{2}{*}{ Row totals } & 41 & 9 & 9 & 7 & 38 & 105 \\
\hline & \multicolumn{6}{|c|}{ Row \% } \\
\hline QB4.1 Yes & 51.22 & 66.67 & 55.56 & 62.50 & 97.37 & $\mathrm{n} / \mathrm{a}$ \\
\hline QB4.1 No & 29.27 & 33.33 & 33.33 & 37.50 & 0.00 & $\mathrm{n} / \mathrm{a}$ \\
\hline QB4.1 Don't know & 19.51 & 0.00 & 11.11 & 0.00 & 2.63 & $\mathrm{n} / \mathrm{a}$ \\
\hline Row totals & 100 & 100 & 100 & 100 & 100 & $\mathrm{n} / \mathrm{a}$ \\
\hline
\end{tabular}

Source: Questions B6.8 and B4.2

Pearson chi-square: $26.4509 ; \mathrm{df}=8 ; p=0.000880$ 
TABLE 12

Summary frequency QB6.8(5) × QB5(4): table Top management's ethical leadership and who should be responsible for ethics in the organisation

\begin{tabular}{|c|c|c|c|c|c|c|}
\hline QB6.8 & Unknown & $\begin{array}{c}\text { Known but considered } \\
\text { unimportant }\end{array}$ & $\begin{array}{c}\text { Known and considered } \\
\text { unimportant }\end{array}$ & $\begin{array}{l}\text { Implementation is } \\
\text { planned }\end{array}$ & Implemented & All Groups \\
\hline & \multicolumn{6}{|c|}{ Count } \\
\hline QB5 HR manager & 14 & 0 & 0 & 3 & 17 & 34 \\
\hline QB5 CEO & 19 & 4 & 6 & 4 & 9 & 42 \\
\hline QB5 Ethics officer & 5 & 3 & 1 & 1 & 2 & 12 \\
\hline QB5 Other & 3 & 2 & 1 & 0 & 10 & 16 \\
\hline \multirow[t]{2}{*}{ Row totals } & 41 & 9 & 8 & 8 & 38 & 104 \\
\hline & \multicolumn{6}{|c|}{ Row \% } \\
\hline QB5 HR manager & 34.15 & 0.00 & 0.00 & 37.50 & 44.74 & $\mathrm{n} / \mathrm{a}$ \\
\hline QB5 CEO & 46.43 & 44.44 & 75.00 & 50.00 & 23.68 & $n / a$ \\
\hline QB5 Ethics officer & 12.20 & 33.33 & 12.50 & 12.50 & 5.26 & $\mathrm{n} / \mathrm{a}$ \\
\hline QB5 Other & 7.32 & 22.22 & 12.50 & 0.00 & 26.32 & $\mathrm{n} / \mathrm{a}$ \\
\hline Row totals & 100 & 100 & 100 & 100 & 100 & $\mathrm{n} / \mathrm{a}$ \\
\hline
\end{tabular}

Source: Questions B6.8 and B5

Pearson chi-Square: $24.1688, \mathrm{df}=12 ; p=0.019302$

TABLE 13

Test of means against constant reference value

\begin{tabular}{|c|c|c|c|c|c|c|}
\hline Variable & Mean & s.d. & $N$ & Reference Constant & $P$ & Effect Size \\
\hline QB6.1 (code of ethics) & 3.48 & 1.70 & 112 & 3 & 0.0034 & 0.28 (Small) \\
\hline QB6.3 (ethics training) & 2.38 & 1.61 & 112 & 3 & 0.0001 & 0.39 (Medium) \\
\hline QB6.4 (reward structures) & 2.04 & 1.46 & 112 & 3 & 0.0000 & 0.66 (Large) \\
\hline QB6.6 (ethics committee) & 1.98 & 1.46 & 112 & 3 & 0.0000 & 0.70 (Large) \\
\hline QB6.7 (whistle-blower protection) & 2.60 & 1.75 & 112 & 3 & 0.0181 & 0.23 (Small) \\
\hline B6 total & 2.48 & 1.16 & 112 & 3 & 0.0000 & 0.45 (Medium) \\
\hline B7.1r (code of ethics) & 4.45 & 0.98 & 112 & 3 & 0.0000 & 1.47 (Large) \\
\hline B7.2r (ethics training) & 3.98 & 1.05 & 112 & 3 & 0.0000 & 0.94 (Large) \\
\hline B7.3r (reward systems) & 3.31 & 1.30 & 112 & 3 & 0.0133 & 0.24 (Small) \\
\hline B7.6r (whistle-blower protection) & 4.22 & 1.02 & 112 & 3 & 0.0000 & 1.20 (Large) \\
\hline B7.7r (ethics Committee) & 3.63 & 1.20 & 112 & 3 & 0.0000 & 0.53 (Medium) \\
\hline B7 total & 3.94 & 0.84 & 112 & 3 & 0.0000 & 1.13 (Large) \\
\hline B9 total & 4.39 & 0.53 & 112 & 3 & 0.0000 & 2.64 (Large) \\
\hline B10.2r (ethics training) & 4.18 & 0.77 & 112 & 3 & 0.0000 & 1.53 (Large) \\
\hline B10.3r (code of ethics) & 4.48 & 0.68 & 112 & 3 & 0.0000 & 2.17 (Large) \\
\hline B10.5r (whistleblower protection) & 4.23 & 0.82 & 112 & 3 & 0.0000 & 1.49 (Large) \\
\hline B10.6r (reward systems) & 3.54 & 1.09 & 112 & 3 & 0.0000 & 0.49 (Medium) \\
\hline B10 total & 4.03 & 0.67 & 112 & - & 0.0000 & 1.54 (Large) \\
\hline
\end{tabular}

Source: question B6.1; B6.3; B6.4; B6.6; B6.7; B7.1; B7.2; B7.3; B7.6; B7.7; B9; B10.2; B10.3; B10.5; B10.6

s.d., standard deviation.

an ethical organisation and to analyse and interpret the data obtained from the empirical study. The key findings from our empirical work can be summarised as follows. The majority of organisations included in the sample do not implement specifically recommended interventions, with the exception of a code of ethics, to create and sustain an ethical organisational environment. However, the majority of respondents believe that it is important that the organisation be seen as ethical and have identified that behaving ethically can result in benefits for the organisation.

It is apparent from this study that CEOs are seen as the lead individuals in implementing ethics in the organisation. The leadership role is also supported by the Human Resource manager in the organisation. However, it became clear that most respondents viewed the CEO's commitment as peripheral, with the perception that the CEO did not portray the expected dedication and commitment to establishing an ethical organisation. According to this study, the vast majority of respondents were left unclear about the extent to which top management should and would provide ethics leadership within the organisation. This issue is also addressed by the King Report III (South African Institute of Chartered Accounts, 2009) principle 1.19, where it requires that the CEO should ensure that a positive and ethical work environment exists.

The model can therefore be viewed as a map which would guide organisations with the appropriate steps when attempting to change or strengthen their ethical environment. Implementing the critical interventions highlighted in the model would portray an organisation's commitment to ethics.

\section{Limitations}

A possible limitation of the study is that it was confined only to the automotive cluster in the Eastern Cape. The study could have been extended across industries and this in turn would have resulted in a higher response rate.

The findings of the empirical study reflect the state of the ethical environment and the adoption of interventions only at the time of the study. Previous interventions that were unsuccessfully implemented and anticipated interventions were not investigated in the empirical study.

An additional limitation but also an area for future research would be to assess the ethical environment of a selected organisation, implement the proposed model of this study and thereafter assess the impact of the model on the organisation's ethical environment.

\section{RECOMMENDATIONS}

The ethical conduct of employees in an organisation is of critical importance to the sustained success of an organisation in the contemporary business environment. This is underpinned by the media coverage of the ethical conduct or lack thereof by numerous organisations worldwide. It is furthermore 
emphasised by the publication and adoption of the various King Reports on Corporate Governance and Ethics.

The importance of this study is that it proposes a model that provides a logical, practical and uncomplicated set of guidelines to organisations in general, with the intention of establishing or improving the ethics in an organisation. Furthermore, the strength of the model and an added factor of importance is the fact that the model distinguishes between critical and optional interventions, where the critical interventions will prove to be the foundation of the process to institutionalise the ethical behaviour of employees within organisation. Lastly, this study set out to test this model and its practicality in evaluating and addressing the ethical nature of organisations, based on a sample organisation within a large sector of the South African economy, namely the automotive industry.

Based on this study it is recommended that organisations should:

- evaluate the ethical climate and nature of their respective organisations

- implement relevant ethics interventions as identified in this study

- identify custodians of the organisational ethics processes

- comply with the recommendations and process frameworks of the respective King Reports on Corporate Governance and Ethics and

- change their business process in order to strengthen ethical structures and in so doing promote the long term sustainability of their organisation in the overall economy.

It is recommended that South African organisations should attempt to position themselves by strengthening their ethical structures and processes in order to promote their organisation and increase their sustainability as a business entity.

In addition it is recommended that future studies and interventions should be formulated around the following issues, namely:

- The reasons for the lack of adoption of the proposed interventions of the model.

- An analysis of the codes of ethics of individual organisations in order to ascertain the reasons for the failure of implementing or adopting an ethical organisational structure.

- The appointment processes followed within ECMIC when appointing executives into their positions. This is an issue specifically highlighted by the King Report III, principle 1.19 .

- An evaluation of the ethics process followed in ECMIC based on the recommended principles of the King III report.

\section{REFERENCES}

Carroll, A.B., \& Buchholtz, A.K. (2003). Business and society:Ethics and stakeholder management (5th edn.). Cincinnati: Thomson Learning.

Cassell, C., Johnson, P., \& Smith, K. (1997). Opening the black box: Corporate codes of ethics in their organisational context. Journal of Business Ethics,16, 1077-1093.

Charlesworth, M., \& Sewry, D. (2003). Preliminary Results of a survey of South African IT Industry Professionals into ethics. Retrieved June 07, 2010, from http://homes. is.ru.ac.za/M.Charlesworth/Thesis/SAICSIT2003. pdfG1St2GiuI_2WPmk2Aw

Costa, J.D. (1998). The ethical imperative: Why moral leadership is good business. Boston: Addison-Wesley.

Czernowalow, M. (2003). South African companies take up sustainability reporting challenge. Engineering News. Retrieved June 07, 2010, from http://www.engineeringnews. co.za/article/sa-companies-take-up-sustainabilityreporting-challenge-2003-10-23
Darley, J.M., Messick, D.M., \& Tyler, T.R. (2001). Social influences on ethical behaviour in organisations. New Jersey: Lawrence Erlbaum.

Deloitte LLP Ethics \& Workplace Survey (2007). Retrieved June 07, 2010, from http://www.deloitte.com/view/en_US/us/ press/Press-Releases/8aa3cb51ed812210VgnVCM100000ba4 2f00aRCRD.htm

Dessler, G. (1997). Human Resource Management (7th edn.). Upper Saddle River: Prentice-Hall.

DiPiazza, S.A. (2001). The value of the corporate ethics officer (Speech). New York City: Conference board Retrieved July 20, 2002, from http://www.ethics.org

Ebert, R.J., \& Griffin, R.W. (2000). Business essentials (3rd edn.). Upper Saddle River: Prentice-Hall.

Emiliani, M.L. (2000). The oath of management. Management Decision, 38(4), 261-262.

Erasmus, B. (2002). Aspects of ethics in Human Resource Management. Management Today, 18(1), 34-38.

Esterhuyse, W. (1999). Are ethics our weak link? People Dynamics, 17(10), 27-31.

Fülöp, G., Hisrich, R.B., \& Szegedi, K. (2000). Business ethics and social responsibility in transition economies. Journal of Management Development, 19(1), 1-3.

Goosen, X., \& Van Vuuren, L.J. (2005) Institutionalising ethics in organizations. The role of mentoring, 3(3), 61-71.

Gottlieb, J.Z., \& Sanzgiri, J. (1996). Towards an ethical dimension of decision-making in organisations. Journal of Business Ethics, 15, 1275-1285.

Kay, S., \& Popkin, S.J. (1998). Integrating ethics into the strategic management process: Doing well by doing good. Management Decision, 36(5), 331-338.

Kile, D.A. (1992). How to set up a steering committee for business conduct and ethics. Albany Law Review, 56(2), 1-11.

Kitson, A., \& Campbell, R. (1996). The ethical organisation: Ethical theory and corporate behaviour. London: Macmillan.

Koehn, D. (1998). Extolling the virtues of hot lines. Online Journal of Ethics. Retrieved June 19, 2002, from http://www. workforce.com/archive/article

KPMG Ethics survey. (2001). Retrieved June 07, 2010, from http://docs.google.com/viewer?a=v\&q=cache:Vyl1u1X9Cag J:www.info.gov.za/

Kreuze, J.G., Luqmani, Z., \& Luqmani, M. (2001). Shades of gray. Internal Auditor, 58(2), 48.

Kreitner, R., \& Kinicki, A. (2001). Organisational behaviour (5th edn.). Boston: Irwin

Lindsay, R.M., Lindsay, L.M., \& Irvine, V.B. (1996). Instilling ethical behaviour in organisations: A survey of Canadian companies. Journal of Business Ethics, 15, 393-407.

Logsdon, J.M., \& Yuthas, K. (1997). Corporate social performance, stakeholder orientation, and organisational moral development. Journal of Business Ethics, 16, 1213-1226.

Malan, F., \& Smit, B. (2001). Ethics and leadership in business and politics. Lansdowne: Juta.

Mathis, R.L., \& Jackson, J.H. (2000). Human Resource Management (9th edn.). Cincinnati: South-Western Thomson Learning.

McDonald, G., \& Pak, C.P. (1996). It's all fair in love, war and business: Cognitive philosophies in ethical decisionmaking. Journal of Business Ethics, 15, 973-996.

McNamara, M.C. (1999). Complete guide to ethics management: An ethics toolkit for managers. Retrieved February 02, 2000, from http://www.mapnp.org/library/ethics.html

Navran, F. (1997). 12 Steps to building a best-practices ethics program. Workforce, 76(9), 117-122.

Nicolaides, A. (2009). Business Ethics in Africa. Journal of Contemporary Management, 6, 490-501.

Richter, L., Burke, F., \& Doig, J.W. (1990). Combating corruption. Encouraging ethics. Whistle Blowing. American Society for Public Administration, 195-201.

Rossouw, D. (2002). Business ethics in Africa (2nd edn.). Cape Town: Oxford University Press.

Rossouw, D., \& Van Vuuren, L. (2010). Business Ethics (4th edn.). Cape Town: Oxford University Press. 
Rossouw, G.J. (2002). Business ethics and corporate governance in the Second King Report: Farsighted or futile? Koers 67(4) 405-419.

Rossouw, G.J. (2008). Aristotle in the modern corporation: from codes of ethics to ethical culture. Phronimon, 9(1) 77-84.

Robbins, S.P., \& Judge, T.A. (2007). Organisational Behaviour (12th edn.). Upper Saddle River: Pearson-Prentice Hall.

Salopek, J.J. (2001). Do the right thing. Training and Development, 55(7), 1-8. Retrieved August 25, 2002, from http://www. emeraldlibrary.com

South African Institute of Chartered Accountants. (2009) Summary of report on King Committee on Governance. Governance for South Africa (King III). Retrieved June 04, 2010, from http://www.saica.co.za

Spangebarg, H., \& Theron, C.C. (2005). Promoting ethical behaviour through leadership of ethics. The development of the ethical leadership inventory, 36(2).
Trevino, L.K., \& Nelson, K.A. (1995). Managing business ethics: Straight talk about how to do it right. New York: Wiley.

Trevino, L.K., \& Nelson, K.A. (1999). Managing business ethics: Straight talk about how to do it right (2nd edn.). New York: Wiley.

Van Vuuren, L.J. (2002). Institutionalising business ethics: A multi-level ethics strategy. Management Dynamics, 2, 21-27.

White, W.L., Sharar, M.S., \& Funk, R. (2001). Elevating the business ethics of employee assistance. Behavioural Health Management, 21(4), 38-43.

Winstanley, D., \& Woodall, J. (2000). Ethical issues in contemporary Human Resource Management. Suffolk: Macmillan Business.

Wixley, T., \& Everingham, G. (2002). Corporate governance. Cape Town: Siber. 